\title{
Testing for viral material in water of public bathing areas of the Danube during summer, Vojvodina, Serbia, 2014
}

\author{
A Jovanović Galović ${ }^{12}$, S Bijelović ${ }^{12}$, V Milošević ${ }^{12}$, I Hrnjaković Cvjetkovic ${ }^{12}$, M Popović ${ }^{12}$, G Kovačević ${ }^{12}$, J Radovanov Re $^{12}$, N \\ Dragić $^{12}, V^{2}$ Petrović ${ }^{12}$ \\ 1. University of Novi Sad, Faculty of Medicine, Republic of Serbia \\ 2. Institute of Public Health of Vojvodina Novi Sad, Vojvodina, Republic of Serbia
}

Correspondence: Aleksandra Jovanovic Galovic (aleksandra.galovic@izjzv.org.rs)

Citation style for this article:

Jovanović Galović A, Bijelović S, Milošević V, Hrnjaković Cvjetkovic I, Popović M, Kovačević G, Radovanov J, Dragić N, Petrović V. Testing for viral material in water of public bathing areas of the Danube during summer, Vojvodina, Serbia, 2014. Euro Surveill. 2016;21(15):pii=30196. DOI: http://dx.doi.org/10.2807/1560-7917. ES.2016.21.15.30196

Article submitted on 15 April 2015 / accepted on 14 April 2016 / published on 14 April 2016

From August to September 2014 a water quality study was conducted on five popular public Danube beaches in Vojvodina, Serbia. To assess the safety of Danube water for bathing, physical, chemical, bacteriological tests were performed. While many parameters for monitoring the quality of water are regulated by law, there are neither national nor international legislations addressing the presence of viruses in recreational waters. In this study, we performed analyses that surpassed national requirements, and investigated if adenovirus, enterovirus or rotavirus genetic material was present in samples of recreational water collected for quality monitoring. Of 90 water samples obtained during the study, enterovirus material was not found in any sample, but adenovirus and rotavirus genetic materials were respectively detected in 60 and 31 samples. Statistical analyses showed a significant correlation between adenovirus DNA and total coliforms in the water. Even when water samples were adequate for recreational use, adenoviruses were detected in $75 \%(57 / 76)$ of such samples. Our results indicate that implementation of viral indicators in recreational water might be helpful to better assess public health safety. This might be particularly relevant in areas where urban wastewater treatment is insufficient and surface waters affected by wastewater are used for recreation.

\section{Introduction}

Water quality is an essential prerequisite for human health. In the Water Quality and Health Strategy of the World Health Organization, (WHO) 2013-2020 [1], which is centred on the primary prevention of waterborne and water-related diseases, the first strategic objective is to 'obtain the most rigorous and relevant evidence regarding water quality and health'.
While WHO has issued guidelines for safe recreational water environments [2], in the European Union (EU), drinking and bathing water directives (Directive 2000/60/EC, Directive 2006/118/EC, and Directive $2006 / 7 / E C)$ regulate monitoring and management of water for such purposes. Although many parameters are considered for monitoring water quality, there is currently no national or international regulation regarding the presence of viruses in recreational waters.

Epidemics caused by waterborne viral pathogens can occur however, and for persons affected, infection can potentially result in serious complications (hepatitis [3], meningitis [4], myocarditis [5]), even leading to death in some cases. The most important waterborne viruses are enteric viruses, and comprise adenoviruses, enteroviruses (polio, coxsackievirus $A$ and $B$, echovirus), hepatitis $A$ and $E$ viruses, noroviruses I and II, and rotaviruses [6-8].

With respect to drinking water, outbreaks caused by waterborne viruses related to water that met bacteriological standards have been reported $[9,10]$. Viruses on the United States Environment Protection Agency (USEPA)'s drinking water Contaminant Candidate List 4 (CCL 4), a list of "contaminants that are currently not subject to any proposed or promulgated national primary drinking water regulations, but are known or anticipated to occur in public water systems', include viruses of the Calciviridae (norovirus), Picornaviridae (enterovirus), Adenoviridae (adenovirus) families. These groups are internationally considered relevant in terms of public health with a suggestion that they should be part of monitoring $[6,11,12]$ and there is a growing consensus within the scientific community, about the need to implement viral indicators in legislations that define water quality control $[12,13]$. 


\section{FIGURE}

Locations of the beaches investigated for recreational water quality on the Danube in the Autonomous Province of Vojvodina, Serbia, 2014

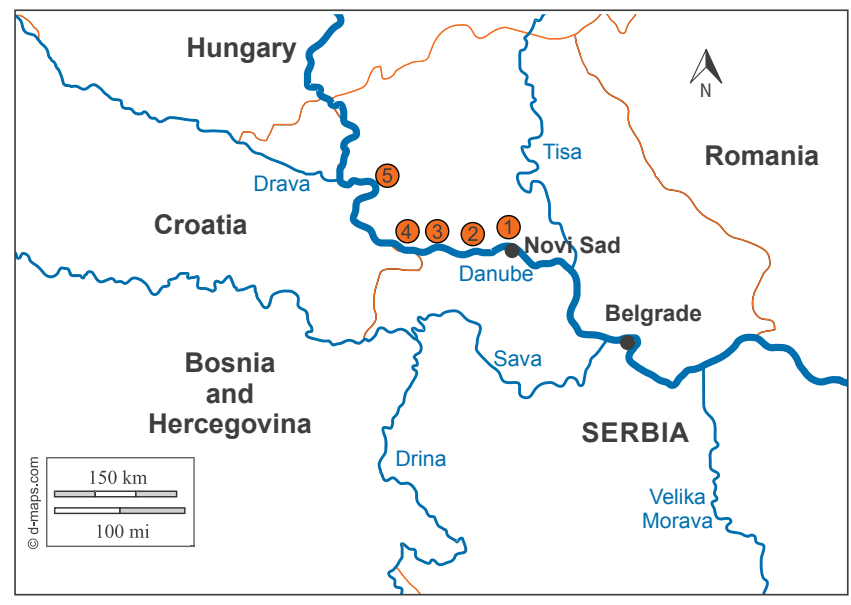

1: 'Strand' Novi Sad; 2: Futog; 3: 'Begecka jama' in Begec; 4: Backa Palanka; 5: Apatin.

The locations where water was sampled are marked in red and numbered from one to five.

Surface waters can become contaminated by viruses through sewage. Individuals with gastroenteritis or hepatitis excrete from $10^{5}$ to $10^{11}$ viral particles per $\mathrm{g}$ of stool [14] and contact or ingestion of water contaminated by faeces might potentially in turn lead to human infections [11]. In surface waters affected by sewage, over 100 viral species may be found $[6,7]$. Still, only some are epidemiologically proven to be transmitted by water. The WHO guidelines for safe recreational water environments include enteroviruses as a regulatory parameter of importance for faecal pollution, but no guideline values are provided due to the 'insufficient data for the development of guideline values' [2].

In Serbia, urban wastewater treatment, although regulated by law [15], is still inadequate, and the sewerage network not complete due to financial and technical difficulties. In this context, faecal contamination of surface water is inevitable $[16,17]$. This represents a potential public health risk especially during bathing season. In the province of Vojvodina, several public beaches on the Danube are crowded with swimmers during the summer. According to the national legislation, physical, chemical and bacteriological parameters of the recreational water are monitored, as well as some biological indicators of water quality (macroinvertebrate, phytobenthos, phytoplankton, and macrophyte analyses). Similar to EU directives however, testing for viruses or viral material is not recognised as part of regular monitoring of bathing waters in the country $[18,19]$.

The objective of our study was to perform analyses that surpass the national requirements and investigate the presence of adenovirus, enterovirus and rotavirus genetic material in recreational waters of the Danube during summer.

\section{Methods}

\section{Water sampling}

The study was conducted from August to September 2014 at five of the most popular beaches on the Danube in the Autonomous Province of Vojvodina, Serbia. The locations investigated were 'Strand' beach in the city of Novi Sad (1,257.57 river kilometre - rkm; measured from the river mouth) as well as beaches near villages and small towns - Futog (1,267.4 rkm); 'Begecka jama' in Begec (1,276.2-1,284 rkm); Backa Palanka (1,298.56 rkm); and Apatin (1,401.90 rkm) (Figure). Eighteen river water samples per location were respectively obtained by collecting three samples per week for a period of six weeks. This corresponded to a total of 90 recreational water samples for all five locations.

Water sampling, transport of samples and analyses of recreational water on site were done according to national standardised methods [20-23]. On site air and water temperatures were measured as recommended by the World Meteorological Organization [24]. Water sampling for virological analyses was done according to the procedure given by Method 1615, USEPA [25]. Briefly, $30 \mathrm{~L}$ of water were collected in pre-sterilised plastic containers. Water samples were taken at waistdepth, $30 \mathrm{~cm}$ below the surface, closed carefully and transported to the laboratory at $4^{\circ} \mathrm{C}$. Upon arrival, the containers were kept in a refrigerated room (at $4^{\circ} \mathrm{C}$ ) until further processing for analysis, which occurred no longer than within $24 \mathrm{~h}$ of sample arrival.

\section{Microbiological indicators and physical and chemical parameters}

For all samples, compliance with National Guideline Values (NGV) for microbiological indicators and physical and chemical parameters (the so-called 'ecological and chemical status') was determined. Analyses were undertaken in laboratories accredited by National Accreditation Bodies. Microbiological parameters defined by national regulation and relevant for this study were: faecal coliform concentration, total coliform concentration, intestinal enterococci concentration and the heterotrophic plate count $[18,19]$. These were determined by the membrane filter method defined in the standardised method, and the Kohl method $[18,19,26]$.

Physical and chemical parameters were: $\mathrm{pH}$ by potentiometry; suspended particulate $(\mathrm{mg} / \mathrm{L})$ and total mineralisation $(\mathrm{mg} / \mathrm{L})$ by gravimetry; dissolved oxygen $(\mathrm{mg} / \mathrm{L}$ ) and chemical oxygen demand (COD) (mg $\left.\mathrm{O}_{2} / \mathrm{l}\right)$ by volumetric titrations; nitrate ( $\mathrm{mg} \mathrm{N} / \mathrm{l}$ ), nitrite ( $\mathrm{mg} \mathrm{N} / \mathrm{l}$ ), ammonium ion (mg $\mathrm{N} / \mathrm{l}$ ), total phosphorus (mg $\mathrm{P} / \mathrm{l}$ ) and orthophosphates (mg $\mathrm{P} / \mathrm{l}$ ) by spectrophotometry (VARIAN Cary 100); biological oxygen demand after five days ( $\left.\mathrm{BOD}_{5}\right)\left(\mathrm{mg} \mathrm{O}_{2} / \mathrm{l}\right.$ ) by volumetric titration [27]; total nitrogen $(\mathrm{mg} \mathrm{N} / \mathrm{l})$ by volumetric 
TABLE 1

Values of microbiological indicators, physical and chemical parameters defining classes of coastal recreational water applicable to Serbia, 2014

\begin{tabular}{|c|c|c|c|c|c|c|}
\hline \multirow{2}{*}{ Parameter } & \multirow{2}{*}{ Units } & \multicolumn{5}{|c|}{ Guideline values } \\
\hline & & Class I & Class II & Class III & Class IV & Class V \\
\hline Faecal coliform concentration & $\mathrm{cfu} / 100 \mathrm{~mL}$ & $\leq 100$ & $\leq 1,000$ & $\leq 10,000$ & $\leq 100,000$ & $\$ 100,000$ \\
\hline Total coliform concentration & $\mathrm{cfu} / 100 \mathrm{~mL}$ & $\leq 500$ & $\leq 10,000$ & $\leq 100,000$ & $\leq 1,000,000$ & $>1,000,000$ \\
\hline Intestinal enterococci concentration & $\mathrm{cfu} / 100 \mathrm{~mL}$ & $\leq 200$ & $\leq 400$ & $\leq 4,000$ & $\leq 40,000$ & $>40,000$ \\
\hline Heterotrophic plate count concentration & $\mathrm{cfu} / 100 \mathrm{~mL}$ & $\leq 500$ & $\leq 10,000$ & $\leq 100,000$ & $\leq 750,000$ & 2750,000 \\
\hline $\mathrm{pH}$ & - & $6.5-8.5$ & $6.5-8.5$ & $6.5-8.5$ & $6.5-8.5$ & $\langle 6.5$ and $>8.5$ \\
\hline Suspended particulate & $\mathrm{mg} / \mathrm{L}$ & $\leq 25$ & $\leq 25$ & NG & NG & NG \\
\hline Total mineralisation & $\mathrm{mg} / \mathrm{L}$ & 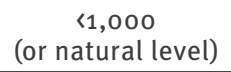 & $\leq 1,000$ & $\leq 1,300$ & $\leq 1,500$ & $>1,500$ \\
\hline Conductivity & $\mu \mathrm{Sv} / \mathrm{cm}$ & $\begin{array}{c}\ll 1,000 \\
\text { (or natural level) }\end{array}$ & $\leq 1,000$ & $\leq 1,500$ & $\leq 3,000$ & $>3,000$ \\
\hline Dissolved oxygen & $\mathrm{mg} \mathrm{O}_{2} / \mathrm{L}$ & $\begin{array}{c}8.5^{\mathrm{a}} \\
\text { (or natural level) } \\
\end{array}$ & $\geq 7^{\mathrm{a}}$ & $\geq 5$ & $\geq 4$ & $<4$ \\
\hline $\begin{array}{l}\text { Oxygen saturation - epilimnion } \\
\text { stratification }\end{array}$ & $\%$ & $90-110$ & $70-90$ & $50-70$ & $30-50$ & $<30$ \\
\hline COD & $\mathrm{mg} \mathrm{O} / \mathrm{L}$ & $\stackrel{5}{5}$ (or natural level) & $\leq 10$ & $\leq 20$ & $\leq 50$ & $>50$ \\
\hline $\mathrm{BOD}_{5}$ & $\mathrm{mg} \mathrm{O}_{2} / \mathrm{L}$ & $\begin{array}{c}2^{\mathrm{a}} \\
\text { (or natural level) }\end{array}$ & $\leq 5^{\mathrm{a}}$ & $\leq 7$ & $\leq 25$ & $>25$ \\
\hline Nitrate $\left(\mathrm{NO}_{3} \cdot \mathrm{N}\right)$ & $\mathrm{mg} \mathrm{N} / \mathrm{L}$ & $\begin{array}{c}1^{\mathrm{a}} \\
\text { (or natural level) }\end{array}$ & $\leq 3^{a}$ & $\leq 6$ & $\leq 15$ & $>15$ \\
\hline Nitrite $\left(\mathrm{NO}_{2} \cdot \mathrm{N}\right)$ & $\mathrm{mg} \mathrm{N} / \mathrm{L}$ & $\begin{array}{l}0.01 \\
\text { (or natural level) }\end{array}$ & $\leq 0.03$ & $\leq 0.12$ & $\leq 0.30$ & $>0.30$ \\
\hline Ammonium ion $\left(\mathrm{NH}_{4}-\mathrm{N}\right)$ & $\mathrm{mg} \mathrm{N} / \mathrm{L}$ & $\begin{array}{c}0.10^{\mathrm{a}} \\
\text { (or natural level) }\end{array}$ & $\leq 0.30^{\mathrm{a}}$ & $\leq 0.60$ & $\leq 1.50$ & $>1.50$ \\
\hline Total nitrogen $(\mathrm{N})$ & $\mathrm{mg} \mathrm{N} / \mathrm{L}$ & $\begin{array}{c}1 \\
\text { (or natural level) } \\
\end{array}$ & $\leq 2$ & $\leq 8$ & $\leq 15$ & $>15$ \\
\hline Total phosphorus (P) & $\mathrm{mg} P / \mathrm{L}$ & $\begin{array}{c}0.05 \\
\text { (or natural level) }\end{array}$ & $\leq 0.20^{a}$ & $\leq 0.40$ & $\leq 1$ & $>1$ \\
\hline Orthophosphates $\left(\mathrm{PO}_{4}^{3-}\right)$ & $\mathrm{mg} P / \mathrm{L}$ & $\begin{array}{c}0.02 \\
\text { (or natural level) }\end{array}$ & $\leq 0.10^{\mathrm{a}}$ & $\leq 0.20$ & $\leq 0.50$ & $>0.50$ \\
\hline
\end{tabular}

BOD5: biological oxygen demand after five days; cfu: colony forming unit; COD: chemical oxygen demand; NG: no guideline for this class. For a water sample to belong to a given class, all the parameter values in the corresponding column for this class have to be fulfilled.

a Depends on the type and coastal water magnitude. Analysed samples are from the Danube, a river defined by national regulation as river

Type I (i.e. large lowland river, with dominance of fine drifts); guideline values provided in Table 1 for Class I and II are valid for a Type I river $[18,19]$.

titrations [28]; conductivity electrochemically $(\mu \mathrm{S} / \mathrm{cm})$ (METTLER TOLEDO SevenMulti); turbidity by turbidimetry (nephelometric turbidity units - NTU) $(\mathrm{HACH} 2100 \mathrm{~N}$ Laboratory Turbidimeter) and oxygen saturation by computing.

According to the national regulation five classes of coastal recreational water by decreasing quality are defined (I, II, III, IV and V), whereby the first three classes (I-III) are considered adequate for human recreational needs, fish farming and drinking - after treatment $[18,19]$. The microbiological indicators, physical and chemical parameters for each class are described in Table 1 . There is no national guideline value for turbidimetry in recreational water $[18,19]$.
Study of viral material present in the water Assessing the presence of viruses in water is not defined by the current national legislation, so it was performed according to internationally recognised methodology with minor modifications [29]. Briefly, $30 \mathrm{~L}$ of river water was filtered with nanoceramic filters (NanoCeram-VS Virus Sampler Filter Cartridges, Argonide Corp., US) allowing negatively-charged virus particles to be absorbed onto the positively-charged nanoceramic filters. Following elution with $500 \mathrm{~mL}$ of elution buffer (1.5\% dessicated beef extract (SigmaAldrich) containing $0.05 \mathrm{M}$ glycine (Sigma-Aldrich) $\mathrm{pH}$ 9.0), the eluate was concentrated by organic flocculation whereby viral particles attached to beef extract proteins at $\mathrm{pH} 3.5$ and were pelleted by centrifugation for $15 \mathrm{~min}$ at $2,500 \times \mathrm{g}$ at $4^{\circ} \mathrm{C}$. The pellet was resuspended in $15 \mathrm{~mL}$ of $0.15 \mathrm{M}$ phosphate buffer $\mathrm{pH}$ 7.0. The sample was further concentrated by ultrafiltration using 
Description of key variables ${ }^{\text {a }}$ relevant to the investigation of Danube water quality at different locations, Vojvodina, Serbia, 2014

\begin{tabular}{|c|c|c|c|c|c|c|c|c|c|}
\hline Location & $\begin{array}{c}\text { Faecal coliform } \\
\text { cfu/100 mL } \\
A V \pm S D\end{array}$ & $\begin{array}{c}\text { Total coliforms } \\
\text { cfu/100 mL } \\
A V \pm S D\end{array}$ & $\begin{array}{c}\text { Intestinal } \\
\text { enterococci } \\
\text { cfu/100 mL } \\
\text { AV }\end{array}$ & $\begin{array}{l}\text { Air T on } \\
\text { site } \\
{ }^{\circ} \mathrm{C} \\
\mathrm{AV} \pm \mathrm{SD}\end{array}$ & $\mathrm{pH}$ & $\begin{array}{l}\text { Nitrate } \\
(\mathrm{NO} \cdot \mathrm{N}) \\
\mathrm{mg} \mathrm{N} / \mathrm{L} \\
\mathrm{AV} \pm \mathrm{SD}\end{array}$ & $\begin{array}{l}\text { Nitrite } \\
\left(\mathrm{NO}_{2} \cdot \mathrm{N}\right) \\
\mathrm{mg} \mathrm{N} / \mathrm{L} \\
\mathrm{AV} \pm \mathrm{SD}\end{array}$ & $\begin{array}{c}\text { Ammonium ion } \\
\left(\mathrm{NH}_{4} \cdot \mathrm{N}\right) \\
\mathrm{mg} \mathrm{N} / \mathrm{L} \\
\mathrm{AV} \pm \mathrm{SD}\end{array}$ & $\begin{array}{l}\text { Turbidity } \\
\text { NTU } \\
\text { AV } \pm \text { SD }\end{array}$ \\
\hline Strand & $\begin{array}{c}4,772.22 \pm \\
4,368.17\end{array}$ & $\begin{array}{c}1,1961.11 \pm \\
6,876.14\end{array}$ & $1,000^{c}$ & $\begin{array}{c}18.82 \pm \\
2.43\end{array}$ & $\begin{array}{c}8.01 \\
\pm \\
0.08\end{array}$ & $\begin{array}{c}0.99 \pm \\
0.12\end{array}$ & $\begin{array}{l}0.01 \pm \\
0.006\end{array}$ & $0.39 \pm 0.14$ & $33.16 \pm 15 \cdot 51$ \\
\hline Futog & $\begin{array}{c}4,894 \cdot 44 \pm \\
4,695 \cdot 11\end{array}$ & $\begin{array}{c}12,838.89 \pm \\
5,218.42\end{array}$ & $9,000^{c}$ & $\begin{array}{c}19.95 \pm \\
2.48\end{array}$ & $\begin{array}{c}7.99 \\
\pm \\
0.08\end{array}$ & $0.91 \pm 0.12$ & $\begin{array}{l}0.02 \pm \\
0.006\end{array}$ & $0.34 \pm 0.12$ & $\begin{array}{c}31.44 \pm \\
14.91\end{array}$ \\
\hline $\begin{array}{l}\text { Begecka } \\
\text { jama }\end{array}$ & $\begin{array}{c}2,966.67 \pm \\
3,185.63\end{array}$ & $\begin{array}{l}7,127 \cdot 78 \pm \\
4,450.22\end{array}$ & $1,400^{d}$ & $\begin{array}{c}19 \cdot 51 \pm \\
2.73\end{array}$ & $\begin{array}{c}8.16 \\
\pm \\
0.21\end{array}$ & $\begin{array}{c}0.22 \pm \\
0.20\end{array}$ & $\begin{array}{l}0.01 \pm \\
0.006\end{array}$ & $0.46 \pm 0.29$ & $8.40 \pm 3.40$ \\
\hline $\begin{array}{l}\text { Backa } \\
\text { Palanka }\end{array}$ & $\begin{array}{c}1,805.56 \pm \\
1,436.28\end{array}$ & $\begin{array}{c}7,050.00 \pm \\
3,189.73\end{array}$ & $1,000^{c}$ & $\begin{array}{c}18.37 \pm \\
3.68\end{array}$ & $\begin{array}{c}8.06 \\
\pm \\
0.19\end{array}$ & $\begin{array}{l}0.01 \pm \\
0.006\end{array}$ & $\begin{array}{l}0.01 \pm \\
0.006\end{array}$ & $0.26 \pm 0.09$ & $24.60 \pm 8.69$ \\
\hline Apatin & $772.22 \pm 505.04$ & $\begin{array}{c}2,394.44 \pm \\
2,084 \cdot 53\end{array}$ & $2,000^{c}$ & $\begin{array}{c}21.25 \pm \\
3.60\end{array}$ & $\begin{array}{c}8.19 \\
\pm \\
0.32\end{array}$ & $\begin{array}{l}0.02 \pm \\
0.006\end{array}$ & $\begin{array}{l}0.01 \pm \\
0.006\end{array}$ & $0.20 \pm 0.13$ & $5.52 \pm 2.08$ \\
\hline
\end{tabular}

AV: average (arithmetic mean); CFU: colony forming unit; N: nitrogen; NTU: nephelometric turbidity unit; SD: standard deviation; T: temperature.

a Only key variables from Table 1 were statistically analysed for the purpose of this study. Accordingly heterotrophic plate count and other physical and chemical parameters showed in Table 1 were not taken into further statistical consideration.

${ }^{b}$ Because of the small number of water samples where intestinal enterococci were detected, these were not taken into consideration for further statistics.

'Value determined in only one of 18 samples.

${ }^{\mathrm{d}}$ Average value calculated according to number of intestinal enterococci determined in two of 18 samples.

Amicon Ultra-15, 30K device (Milipore) to obtain $0.5 \mathrm{~mL}$ of sample. Viral nucleic acids (DNA, RNA) were isolated by Ribo Virus kit (Sacace Biotechnologies, Italy), and analysed by real-time polymerase chain reaction (PCR) using a real-time thermocycler Applied Biosystems 7500 (Applied Biosystems, US) as well as the following kits for human diagnostics: RIDAGENE Rotavirus/ Adenovirus Duplex (R-Biopharm AG, Germany); Enterovirus Real-TM (Sacace Biotechnologies, Italy).

\section{Statistics}

For data processing, the standard parametric and nonparametric statistical methods were used. Numerical data are presented through the arithmetic mean and standard deviation, while qualitative data are assessed by frequency of distribution. To check the normality of continuous data we used Shapiro-Wilk normality test, along with the normal-probability plots. Data of faecal coliforms were $\log _{10}$ transformed to meet assumptions of normality, while transformation (squareroot and $\log _{10}$ ) of data for total coliforms did not improve their normality. In accordance with the objectives of the analyses and nature of the data, Spearman's correlation coefficient, Fisher exact test, Mann-Whitney U test and Student's t-test were used. Data of faecal coliforms were log transformed to meet assumptions of normality for the Student's $t$-test. In all statistical analyses the presence of viruses was examined as a dependent variable, and coded as ' 1 ' to indicate absence of viruses and ' 2 ' to indicate presence of viruses. Results were considered statistically significant when the $p$ value for all the applied models was $<0.05$ and the corresponding $95 \%$ confidence interval $(95 \% \mathrm{Cl})$ did not include 1.0 (Student's $t$-test). For all statistical analyses the statistical package SPSS (version 17), Microsoft Office Excel 2003 and Microsoft Visual Fox Pro were used.

\section{Results}

\section{Chemical and microbiological findings}

In terms of microbiological parameters, the average concentration of faecal coliforms ranged from $772.22 \pm 505.04 \mathrm{cfu} / 100 \mathrm{~mL}$ on Apatin beach to $4,894.44 \pm 4,695.11 \mathrm{cfu} / 100 \mathrm{~mL}$ on Futog beach, while the average total coliform concentration was in the range of $2,394.44 \pm 2,084.53 \mathrm{cfu} / 100 \mathrm{~mL}$ to $12,838.89 \pm 5,218.42 \mathrm{cfu} / 100 \mathrm{~mL}$, at the same respective locations (Table 2).

For chemical analyses, the minimum average value of $\mathrm{pH}(7.99 \pm 0.08)$ and nitrite (0.02 mg nitrogen/ $\mathrm{mL} \pm 0.006$ ) was found at Futog, while the minimum average value of nitrate (0.01 mg nitrogen $/ \mathrm{mL} \pm 0.006$ ) was at Backa Palanka. The highest average value of ammonium ion (0.46 mg nitrogen $/ \mathrm{mL} \pm 0.29$ ) was found at Begecka jama. Average values of turbidity ranged between $5.52 \mathrm{NTU} \pm 2.08$ and $33.16 \mathrm{NTU} \pm 15.51$ at Apatin and Strand, respectively (Table 2). 
TABLE 3

Quality of the water samples at different locations on the Danube in terms of class of recreational water and presence of viral material, Vojvodina, Serbia, 2014

\begin{tabular}{|c|c|c|c|c|c|c|c|}
\hline \multirow[b]{2}{*}{ Location } & \multirow[b]{2}{*}{ Samples } & \multicolumn{3}{|c|}{ Suitable for recreation } & \multicolumn{3}{|c|}{ Unsuitable for recreation } \\
\hline & & $\begin{array}{c}\text { Class II } \\
\mathrm{N}\end{array}$ & $\begin{array}{c}\text { Class III } \\
\mathrm{N}\end{array}$ & $\begin{array}{c}\text { Total } \\
\mathrm{N}\end{array}$ & $\begin{array}{c}\text { Class IV } \\
\mathrm{N}\end{array}$ & $\begin{array}{c}\text { Class V } \\
\mathrm{N}\end{array}$ & $\begin{array}{c}\text { Total } \\
\mathrm{N}\end{array}$ \\
\hline \multirow{3}{*}{$\begin{array}{l}\text { Strand } \\
\text { (18 samples) }\end{array}$} & Totals ${ }^{\mathrm{a}}$ & 2 & 14 & 16 & 2 & 0 & 2 \\
\hline & With adenoviruses & 1 & 11 & 12 & 1 & 0 & 1 \\
\hline & With rotaviruses & 0 & 9 & 9 & 0 & 0 & 0 \\
\hline \multirow{3}{*}{$\begin{array}{l}\text { Futog } \\
\text { (18 samples) }\end{array}$} & Totals $^{a}$ & 1 & 16 & 17 & 1 & 0 & 1 \\
\hline & With adenoviruses & 1 & 14 & 15 & 1 & 0 & 1 \\
\hline & With rotaviruses & 0 & 4 & 4 & 1 & 0 & 1 \\
\hline \multirow{3}{*}{$\begin{array}{l}\text { Begecka jama } \\
\text { (18 samples) }\end{array}$} & Totals $^{\mathrm{a}}$ & 2 & 10 & 12 & 3 & 3 & 6 \\
\hline & With adenoviruses & 2 & 4 & 6 & 0 & 0 & 0 \\
\hline & With rotaviruses & 1 & 1 & 2 & 0 & 0 & 0 \\
\hline \multirow{3}{*}{$\begin{array}{l}\text { Backa Palanka } \\
\text { (18 samples) }\end{array}$} & Totals $^{\mathrm{a}}$ & 2 & 16 & 18 & 0 & 0 & 0 \\
\hline & With adenoviruses & 2 & 15 & 17 & 0 & 0 & 0 \\
\hline & With rotaviruses & 0 & 6 & 6 & 0 & 0 & 0 \\
\hline \multirow{3}{*}{$\begin{array}{l}\text { Apatin } \\
\text { (18 samples) }\end{array}$} & Totals $^{\mathrm{a}}$ & 2 & 11 & 13 & 0 & 5 & 5 \\
\hline & With adenoviruses & 1 & 6 & 7 & 0 & 1 & 1 \\
\hline & With rotaviruses & 2 & 5 & 7 & 0 & 2 & 2 \\
\hline \multirow{3}{*}{$\begin{array}{l}\text { Total } \\
\text { (90 samples) }\end{array}$} & Totals $^{a}$ & 9 & 67 & 76 & 6 & 8 & 14 \\
\hline & With adenoviruses & 7 & 50 & 57 & 2 & 1 & 3 \\
\hline & With rotaviruses & 3 & 25 & 28 & 1 & 2 & 3 \\
\hline
\end{tabular}

$\mathrm{N}$ : number of samples.

None of the water samples were defined as Class I.

a These totals are the number of samples of a certain category of water quality (defined as water class, or as suitable/unsuitable for recreational use) at each location. Adding up the number of samples testing positive for adenoviruses with the number of samples testing positive for rotaviruses in each category, does not necessarily yield the totals presented, because some individual samples could test positive for both adenovirus and rotavirus. Moreover, some samples included in the total could be negative for both types of viruses.

\section{Classification of the coastal recreation water samples}

Taking into account parameters defined by national law - the so called 'chemical and ecological status' for recreational waters, 76 of a total of 90 samples analysed at all locations (84\%) complied to the NGV for recreational use (Table 3).

Considering water class distribution at each beach, full compliance with NGV for recreational use over the whole study period was only observed for Backa Palanka, with all 18 water samples taken at this location corresponding to class II or III (2 samples of class II and 16 of class III).

Of the 18 water samples collected respectively at the other beaches, 13 were of class II or III at Apatin, 12 at Begecka jama, 16 at Strand and 17 at Futog (Table 3). One class IV sample was found at Futog, two at Strand and three at Begecka jama (Table 3). Three water samples corresponding to class $V$ were detected at Begecka jama and five at Apatin.
Presence of viral material in the water and relationship with water quality parameters Enteroviruses were not detected in any of the samples of recreational water analysed, while adenoviruses and rotaviruses were respectively found in 60 (67\%) and 31 (34\%) samples of the total 90 (Table 3 ).

Adenoviruses were predominantly present in water collected at Backa Palanka beach (17 of 18 samples), where all analysed samples were in accordance with NGV (Table 3). Rotaviruses were mostly found on the beaches of Strand in Novi Sad and Apatin (9 and 7 samples respectively) where 16 and 13 samples complied to the NGV respectively.

An analysis by Spearman's correlation showed that regardless of the species, the presence of viral material (i.e. adenoviruses and rotaviruses, taken together), was negatively correlated with the surface water temperature $(p<0.05)$ and positively correlated with nitrite concentration ( $p<0.05$ ) (Table 4$)$. There was no statistically significant relationship to the class distribution of recreational water samples, nor to the concentration of total coliforms and faecal coliforms. 
Spearman rank correlation of microbiological indicators, physical and chemical parameters, water samples status defined as classes and the presence of adenoviruses, rotaviruses, and adenoviruses and rotaviruses taken together, Vojvodina, Serbia, 2014

\begin{tabular}{|c|c|c|c|}
\hline $\begin{array}{l}\text { Microbiological indicators/ physical and chemical parameters of water samples status of } \\
\text { coastal recreational water }\end{array}$ & Adenovirus & Rotavirus & $\begin{array}{l}\text { Adenovirus } \\
\text { and rotavirus }\end{array}$ \\
\hline Faecal coliforms concentration & $0.265^{\mathrm{a}}$ & 0.024 & -0.089 \\
\hline Total coliforms concentration & $0.333^{b}$ & 0.049 & 0.002 \\
\hline $\mathrm{pH}$ value & $-0.214^{a}$ & -0.040 & -0.141 \\
\hline Nitrate $\left(\mathrm{NO}_{3} \cdot \mathrm{N}\right)$ & $0.273^{b}$ & 0.205 & 0.151 \\
\hline Nitrite $\left(\mathrm{NO}_{2}-\mathrm{N}\right)$ & -0.004 & 0.034 & $0.213^{a}$ \\
\hline Ammonium ion $\left(\mathrm{NH}_{4}-\mathrm{N}\right)$ & -0.110 & -0.156 & -0.039 \\
\hline Turbidity & $0.312^{b}$ & -0.012 & -0.007 \\
\hline Temperature of air on site & -0.066 & $-0.290^{b}$ & -0.173 \\
\hline Temperature of water on site & $-0.451^{b}$ & $-0.311^{b}$ & $-0.210^{a}$ \\
\hline Class & $-0.355^{b}$ & -0.080 & -0.077 \\
\hline
\end{tabular}

a Spearman's correlation statistically significant at the level $p<0.05$.

b Spearman's correlation statistically significant at the level $p<0.01$.

When viral species were analysed separately, the presence of rotavirus material was significantly negatively correlated with surface water and air temperatures ( $p<0.01$ for both parameters). No significant relationship to class distribution was observed.

Like for rotavirus, presence of adenovirus material (Table 4) was significantly negatively correlated with temperature of surface water $(p<0.01)$. Water $\mathrm{pH}$ value was negatively correlated $(p<0.05)$. A positive correlation was obtained between presence of adenovirus material and concentrations of faecal coliforms ( $p<0.05)$ and total coliforms ( $p<0.01)$, as well as concentration of nitrate $(p<0.01)$ and turbidity $(p<0.01)$. For class distribution, a negative correlation was found $\left(r_{0}=-0.355, p<0.001\right)$.

The relationship between adenoviruses and coliforms in the water as well as adenoviruses and water class were further explored with other statistical tests.

Samples testing positive for adenovirus material were more frequently found when concentrations of total coliforms (Mann-Whitney $U$ test; $p=0.002$ ) and faecal coliforms ( $t$ test, $p=0.017$ ) were elevated, i.e. $\geq 100,000$ $\mathrm{cfu} / 100 \mathrm{~mL}$ and $\geq 10,000 \mathrm{cfu} / 100 \mathrm{~mL}$ respectively (Table 5).

In terms of the correlation between adenoviruses and class, assessment using the Fisher exact test indicated that even when the water samples corresponded to class I-III ( $n=76$ samples), adenoviruses were detected in $75 \%$ of samples $(n=57)$ in relation to $25 \%$ of samples $(n=19)$, where adenoviruses were not detected $(p=0.000)$.

\section{Discussion}

In this study, we found that 76 of a total of 90 water samples collected at popular beaches on the Danube in Vojvodina during the summer 2014 complied the NGV for recreational use. Further analyses beyond the requirements defined by current legislation however confirm the presence of adenovirus and rotavirus genetic material respectively in 60 and 31 of the 90 obtained water samples. Although data on viruses in environmental water are scarce for Serbia, a recent report also relates detection of adeno- and/or norovirus material in surface waters of Vojvodina province, at 21 of 30 analysed locations [30]. In that report however, only two of the locations investigated were public beaches and sampling was done only once in the bathing season. Our study in contrast was designed to seek viral material in the Danube at five different popular beach locations, throughout the bathing season.

In addition to checking for the presence of viral material in the water, we conducted in parallel the routine law-required analyses for monitoring water quality. Results suggest faecal contamination of recreational waters in the Danube at all investigated locations, with data not differing significantly from those obtained in previous years [31]. A statistically significant positive correlation was moreover obtained between adenovirus material in the Danube and both the nitrate concentration and turbidity of the water, which are parameters related to faecal contamination. Corroborating these results, adenovirus genetic material was also significantly positively correlated with concentrations of total coliforms and faecal coliforms.

The results found here are in agreement with those of a large European study (EU FP6 Project VIROBATHE study) [13], where significant trends were observed 
Association between the presence of adenovirus, class distribution and the number of faecal coliforms and total coliforms concentration in analysed recreational samples, Vojvodina, Serbia, 2014

\begin{tabular}{|c|c|c|c|c|c|c|c|c|c|c|}
\hline \multirow{2}{*}{$\begin{array}{l}\text { Detection of } \\
\text { adenoviruses }\end{array}$} & \multicolumn{3}{|c|}{$\begin{array}{c}\text { Fisher's exact test } \\
\text { Water samples classes }\end{array}$} & \multicolumn{3}{|c|}{$\begin{array}{l}\text { Independent samples } t \text { test } \\
\log _{10} \text { of faecal coliforms }\end{array}$} & \multicolumn{4}{|c|}{$\begin{array}{l}\text { Mann-Whitney } U \text { test } \\
\text { Total number of coliforms }\end{array}$} \\
\hline & $\begin{array}{l}\text { Class I-III } \\
\quad \mathrm{N}(\%)\end{array}$ & $\begin{array}{l}\text { Class IV-V } \\
\mathrm{N}(\%)\end{array}$ & P value ${ }^{d}$ & $\mathrm{~N}$ & $\mathrm{GM}^{\mathrm{b}} \pm \mathrm{SD}$ & Significance & $\mathrm{N}$ & $\begin{array}{l}\text { Sum of } \\
\text { Ranks }\end{array}$ & $Z^{c}$ & $P$ value \\
\hline Neg. & $19(25)$ & $11(79)$ & \multirow{2}{*}{0.000} & 30 & $\begin{array}{c}3.08 \pm \\
0.39\end{array}$ & \multirow{2}{*}{$\begin{aligned} t^{\mathrm{e}} & =2.218 \\
d^{\mathrm{f}} & =88 \\
\mathrm{p} & =0.017^{\mathrm{g}}\end{aligned}$} & 30 & 999 & - & \multirow[b]{2}{*}{0.002} \\
\hline Pos. & $57(75)$ & $3(21)$ & & 60 & $\begin{array}{l}3.32 \pm \\
0.472\end{array}$ & & 60 & 3,096 & 3.138 & \\
\hline
\end{tabular}

G: geometric mean; N: number of samples; neg.: negative for adenovirus; pos.: positive for adenovirus; SD: standard deviation.

${ }^{a}$ According to national regulations the first three classes (I-III) allows using the coastal water for human recreational needs including for fish farming and, after adequate treatment, for drinking.

${ }^{b} 10^{x}$, where $X$ is the mean of $\log _{10}$ transformed values.

c $Z$ value of Mann-Whitney $U$ test.

${ }^{d} p$ significant (2-tailed).

${ }^{e} t$ value of independent samples $t$ test.

${ }^{f}$ Equal variances not assumed (tested with Levine's test for variance).

${ }^{g}$ Significant with $95 \%$ confidence interval: -0.47 to -0.04 .

between categories of increasing faecal indicator organism concentration (Escherichia coli, intestinal enterococci and somatic coliphage) and increasing proportions of human adenovirus-positive results in freshwater. An explanation for the results, may lie in the fact that human adenovirus has been detected at high concentration in faeces of infected individuals $\left(10^{6}\right.$ per $g$ of stool) [32].

Quantitative analyses of adenovirus genetic material in European recreational waters in 2010 found $3.2 \mathrm{x}$ $10^{2}$ genomic copies of adenovirus per $100 \mathrm{~mL}$ water on average [33], while in another study of the EU FP6 Project VIROBATHE, Wyn-Jones et al. [12] detected adenoviruses in $36 \%$ of the samples that they collected in diverse freshwater and marine sites in Europe. The finding that 60 of $90(67 \%)$ water samples collected in our study were contaminated with adenovirus material, is likely attributable to the absence of adequate urban wastewater treatment in Serbia. While it is clear that the only long-term and comprehensive solution to this problem would be a coordinated action of all stakeholders to prevent the contamination of surface waters, the elimination of raw sewage entering rivers may require a number of important measures (e.g. management and improvement of sewerage networks and treatment plants, efforts to reduce spills of sewage during rainfall events by storm tanks, separation of surface and foul infrastructure, sustainable urban drainage schemes) and may not be imminent. Therefore a more extensive control of bathing waters may be considered. Indeed, viral infectivity doses for enteric viruses are very low (10-100 virions) and such viruses persist longer (up to 120 days in freshwater) and are more resistant than enterobacteria to some environmental factors (UV radiation, chemicals) [8].
The presence of viral material in freshwater is moreover not limited to Serbia [12,33-36], and in some EU Member States such as Ireland, raw sewage entering environmental water still represents a problem [37]. In this context, an adequate viral indicator for water, together with surveillance of waterborne virus infections, may generally contribute to a more comprehensive hazard assessment for users of this water. In some countries, such as the US, a special surveillance system for waterborne diseases has been put in place $[38,39]$.

Our study additionally suggests that despite a correlation between adenovirus material and coliforms, bacterial analyses alone cannot always predict the presence of viral material in the water. Even when water samples were found to be suitable for recreational use, $75 \%$ of these samples tested positive for adenovirus genetic material. An explanation for this may lie in the fact that adenoviruses have a double stranded DNA genome, which is more sturdy and resistant to various environmental factors than e.g. RNA, which forms the base of rotaviruses' genome. Human adenoviruses are also known to persist longer in the environment than bacterial indicators of faecal contamination and are frequently the most abundant type of virus in surface waters [32]. Because infections with adenovirus may produce serious, even lethal diseases especially in immunocompromised persons, children and elderly [32], monitoring such viruses in recreational water may be of importance.

It should be noted, that the presence of viral material in this study was determined by PCR and does not necessarily mean the presence of infective virus, since PCR detects both non-infective and infective viral genetic material. However, according to the literature data on the survival of adenoviral particles in the environment $[40,41]$ a risk for recreational use could possibly exist. 
In order to establish the presence of infective viral particles, more research using cell culture is needed.

In contrast to adenovirus, rotavirus material was present in much lower proportions of our samples (31 samples with rotavirus vs 60 with adenovirus), and this corroborates with the findings of other authors who did similar testing and found rotaviruses much less present than adenoviruses in surface water contaminated with sewage [42]. Although it is difficult to compare the results from different parts of the world, it might be speculated that this result is due to the lower occurrence of such viruses in the human population, as well as their structure [11]. Having RNA as genetic material might make rotaviruses more vulnerable to environmental conditions, as shown here by a significant correlation between rotavirus material presence and air and water temperature. Due to their lower occurrence, it may be concluded that, although of importance [43], rotaviruses would likely not be suitable candidates as a water viral indicator.

Taken together, our data support the need for more measures to avoid faecal contamination of the Danube, and provide more evidence for the idea of having a viral indicator for recreational waters in order to fully assess public health safety. Such an indicator would be of particular importance in regions like Vojvodina (and even in the whole of Serbia), where urban wastewater treatment is not adequate.

\section{Acknowledgements}

Project was funded by Provincial Secretariat for Science and Technological Development, as a Project of Special Interest for Sustainable Development, Project No. 114-451-445/2014-03.

\section{Conflict of interest}

None declared.

\section{Authors' contributions}

AJG: wrote the manuscript, coordinated the study, performed virology analyses; SB: co-writer of the manuscript, interpreted the results; VM: coordinated the study, interpreted the results, revised the manuscript; $\mathrm{IH}$ : interpreted the results, revised the manuscript; MP: coordinated the study and chemical analyses; GK and JR: performed water samples for virology analyses, performed PCR assays. ND: performed statistical analyses; VP: coordinated the study, revised the manuscript.

\section{References}

1. World Health Organization (WHO). Water Quality and Health Strategy 2013-2020. Geneva: WHO; 2013. Available from: http://www.who.int/water_sanitation_health/ publications/2013/water_quality_strategy/en/

2. World Health Organization (WHO). Guidelines for safe recreational water environments. Volume 1 , Coastal and fresh waters. Geneva: WHO; 2003.

3. Van der Poel WHM. Food and environmental routes of Hepatitis E virus transmission.Curr Opin Virol. 2014;4:91-6. DOI: 10.1016/j.coviro.2014.01.006 PMID: 24513966
4. Rhoades RE, Tabor-Godwin JM, Tsueng G, Feuer R. Enterovirus infections of the central nervous system.Virology. 2011;411(2):288-305. DOI: 10.1016/j.virol.2010.12.014 PMID: 21251690

5. Gaaloul I, Riabi S, Harrath R, Evans M, Salem NH, Mlayeh $S$, et al. Sudden unexpected death related to enterovirus myocarditis: histopathology, immunohistochemistry and molecular pathology diagnosis at post-mortem. BMC Infect Dis. 2012;12(1):212. DOI: 10.1186/1471-2334-12-212 PMID: 22966951

6. La Rosa G, Fratini M, della Libera S, Iaconelli M, Muscillo $M$. Emerging and potentially emerging viruses in water environments.Ann Ist Super Sanita. 2012;48(4):397-406. DOI: 10.4415/ANN_12_04_07 PMID: 23247136

7. Bosch A. Human enteric viruses in the water environment: $a$ minireview.Int Microbiol. 1998;1(3):191-6.PMID: 10943359

8. Fong TT, Lipp EK. Enteric viruses of humans and animals in aquatic environments: health risks, detection, and potential water quality assessment tools. Microbiol Mol Biol Rev. 2005;69(2):357-71. DOI: 10.1128/MMBR.69.2.357-371.2005 PMID: 15944460

9. Bosch A, Lucena F, Díez JM, Gajardo R, Blasi M, Jofre J. Waterborne viruses associated with hepatitis outbreak.J Am Water Works Assoc. 1991;83(3):80-3.

10. Hejkal TW, Keswick B, LaBelle RL, Gerba CP, Sanchez Y, Dreesman $G$, et al. Viruses in a community water supply associated with an outbreak of gastroenteritis and infectious hepatitis. J Am Water Works Assoc. 1982;74(6):318-21.

11. Gibson KE. Viral pathogens in water: occurrence, public health impact, and available control strategies.Curr Opin Virol. 2014;4:50-7. DOI: 10.1016/j.coviro.2013.12.005 PMID: 24440908

12. Wyn-Jones AP, Carducci A, Cook N, D’Agostino M, Divizia M, Fleischer J, et al. Surveillance of adenoviruses and noroviruses in European recreational waters. Water Res. 2011;45(3):102538. DOI: 10.1016/j.watres.2010.10.015 PMID: 21093010

13. Wyer MD, Wyn-Jones AP, Kay D, Au-Yeung H-KC, Gironés R, López-Pila J, et al. Relationships between human adenoviruses and faecal indicator organisms in European recreational waters. Water Res. 2012;46(13):4130-41. DOI: 10.1016/j. watres.2012.04.008 PMID: 22633054

14. Farthing MJG. Viruses and the Gut. Welwyn Garden City, Hertfordshire: Smith Kline \& French; 1989.

15. Official Bulletin of the Republic of Serbia. The Law on Waters. No 30/10. Serbian. Available from: http://www.rdvode.gov.rs/ doc/dokumenta/zakoni/zakon-o-vodama.pdf

16. Vujovic S, Kolakovic S. Intergrated water approach for Serbia's Resurgence. Water World. 2013; 28(4). Available from: http:// www.waterworld.com/articles/wwi/print/volume-28/issue-4/ regional-spotlight/intergrated-water-approach-for-serbia-sresurgence.html

17. Wastewater country profile Serbia and Montenegro, United Nations report 2004. Available from: http://www.un.org/esa/ agenda21/natlinfo/countr/serbia/serbiawastewater.pdf

18. Regulations on the parameters of the ecological and chemical status of surface waters and the parameters of the chemical and quantitative status of groundwater. Official Gazette of the Republic of Serbia. 2011; 74.

19. Regulation on limit values of pollutants in surface and ground waters and sediments, and deadlines for achieving them. Official Gazette of the Republic of Serbia. 2012; 50.

20. Institute for standardization of Serbia (ISS). Testing of water. Measurement of temperature. SRPS H.Z1.106:1970. Beograd: ISS; 1970.

21. Institute for standardization of Serbia (ISS). Water quality - Sampling. Part 1: Guidance on the design of sampling programmes and sampling techniques. SRPS EN ISO $5667-$ 1:2008 (sr). Identical with EN ISO 5667-1:2006 CEN/TC 230 and EN ISO 5667-1:2006/AC: 2007 CEN/TC 230. Beograd: ISS; 2008.

22. Institute for standardization of Serbia (ISS). Water quality Sampling. Part 3: Guidance on the preservation and handling of water samples. SRPS EN ISO 5667-3:2007 (sr). Identical with EN ISO 5667-3:2003 CEN/TC 230. Beograd: ISS; 2007.

23. Institute for standardization of Serbia (ISS). Water quality Sampling. Part 6: Guidance on sampling of rivers and streams. SRPS ISO 5667-6:1997. Identical with ISO 5667-6:1990 ISO/TC 147/SC 6. Beograd: ISS; 1997.

24. World Meteorological Organization (WMO). Guide to Meteorological Instruments and Methods of Observation. WMO, No.8, 2008 edition, updated in 2010. Geneva: WMO; 2012.

25. United States Environmental Protection Agency (EPA). Method 1615, Measurement of Enterovirus and Norovirus Occurrence in Water by Culture and RT-qPCR, EPA 600/R-10/181, December 2010, Version 1.1, Revised January 2012. Washington DC: EPA; 2012. Available from: www.epa.gov/ord 
26. Institute for standardization of Serbia (ISS). Water quality Detection and enumeration of Escherichia coli and coliform bacteria - Part 1: Membrane filtration method. SRPS EN ISO 9308-1:2010. Identical with EN ISO 9308-1:2000 CEN/TC 230 and EN ISO 9308-1:2000/AC:2008 CEN/TC 230. Beograd: ISS;2010.

27. Institute for standardization of Serbia (ISS). Water quality Determination of biochemical oxygen demand after $\mathrm{n}$ days (BODn) - Part 2: Method for undiluted samples (ISO 5815:1989, modified). SRPS EN 1899-2:2009. Identical with EN 18992:1998 CEN/TC 230. Beograd: ISS;2009.

28. Institute for standardization of Serbia (ISS). Water quality - Determination of Kjeldahl nitrogen - Method after mineralization with selenium (ISO 5663:1984). SRPS EN 25663:2009. Identical with EN 25663:1993 CEN/TC 230. Beograd: ISS; 2009

29. Cashdollar JL, Brinkman NE, Griffin SM, McMinn BR, Rhodes ER, Varughese EA, et al. Development and evaluation of EPA method 1615 for detection of enterovirus and norovirus in water. Appl Environ Microbiol. 2013;79(1):215-23. DOI: 10.1128/ AEM.02270-12 PMID: 23087037

30. Lazić G, Grubač S, Lupulović D, Bugarski D, Lazić S, Knežević $P$, et al. Presence of Human and Animal Viruses in Surface Waters in Vojvodina Province of Serbia. Food Environ Virol. 2015;7(2):149-58. DOI: 10.1007/S12560-015-9187-3 PMID: 25687987

31. Arsic M, Ac Nikolic E, Balac D, Bijelovic S, Bjelanovic J, Velick $R$, et al. Health status of population living in the City of Novi Sad. Institute of Public Health of Vojvodina, 2013. Available from: http://izjzv.org.rs/uploads/download/Zdravstveno_ stanje_stanovnistva/Novi\%20Sad/NoviSad_2012.pdf

32. Mena KD, Gerba CP. Waterborne adenovirus.Rev Environ Contam Toxicol. 2009;198:133-67. DOI: 10.1007/978-0-38709647-6_4 PMID: 19253037

33. Bofill-Mas S, Calgua B, Clemente-Casares P, La Rosa G, laconelli M, Muscillo M, et al. Quantification of human adenoviruses in European recreational waters. Food Environ Virol. 2010;2(2):101-9. DOI: 10.1007/s12560-010-9035-4

34. Jiang SC, Chu W. PCR detection of pathogenic viruses in southern California urban rivers.J Appl Microbiol. 2004;97(1):17-28. DOI: 10.1111/j.1365-2672.2004.02269.x PMID: 15186438

35. Albinana-Gimenez N, Miagostovich MP, Calgua B, Huguet JM, Matia L, Girones R. Analysis of adenoviruses and polyomaviruses quantified by qPCR as indicators of water quality in source and drinking-water treatment plants. Water Res. 2009;43(7):2011-9. DOI: 10.1016/j.watres.2009.01.025 PMID: 19230949

36. Ye XY, Ming X, Zhang YL, Xiao WQ, Huang XN, Cao YG, et al. Real-time PCR detection of enteric viruses in source water and treated drinking water in Wuhan, China. Curr Microbiol. 2012;65(3):244-53. DOI: 10.1007/s00284-012-0152-1 PMID: 22645016

37. Environmental Protection Agency. Ireland (EPA). EPA calls for the elimination of raw sewage entering the environment and improvement in the management of wastewater plants. EPA; 2015. [Accessed 10 Apr 2015]. Available from: http://www.epa. ie/newsandevents/news/name,53429,en.html\#.VR58mmeQl9A

38. Brunkard JM, Ailes E, Roberts VA, Hill V, Hilborn ED, Craun GF, et al. . Surveillance for waterborne disease outbreaks associated with drinking water---United States, 2007--2008. MMWR Surveill Summ. 2011;60(12):38-68.PMID: 21937977

39. Hlavsa MC, Roberts VA, Anderson AR, Hill VR, Kahler AM, Orr M, et al. . Surveillance for waterborne disease outbreaks and other health events associated with recreational water -.- United States, 2007--2008.MMWR Surveill Summ. 2011;60(12):1-32.PMID: 21937976

40. Kotwal G, Cannon JL. Environmental persistence and transfer of enteric viruses.Curr Opin Virol. 2014;4:37-43. DOI: 10.1016/j. coviro.2013.12.003 PMID: 24413147

41. Ogorzaly L, Bertrand I, Paris M, Maul A, Gantzer C. Occurrence, survival, and persistence of human adenoviruses and F-specific RNA phages in raw groundwater.Appl Environ Microbiol. 2010;76(24):8019-25. DOI: 10.1128/AEM.00917-10 PMID: 20952644

42. Victoria M, Fumian TM, Rocha MS, Dalmao F, Leite JPG, Girones $R$, et al. Gastroenteric virus dissemination and influence of rainfall events in urban beaches in Brazil. J Appl Microbiol. 2014;117(4):1210-8. DOI: 10.1111/jam.12592 PMID: 24980661

43. Kiulia NM, Hofstra N, Vermeulen LC, Obara MA, Medema G, Rose JB. Global occurrence and emission of rotaviruses to surface waters.Pathogens. 2015;4(2):229-55. DOI: 10.3390/ pathogens4020229 PMID: 25984911

\section{License and copyright}

This is an open-access article distributed under the terms of the Creative Commons Attribution (CC BY 4.0) Licence. You may share and adapt the material, but must give appropriate credit to the source, provide a link to the licence, and indicate if changes were made.

This article is copyright of the authors, 2016. 